DOI: 10.20472/IAC.2017.032.006

\author{
NEMANJA BACKOVIĆ \\ Faculty of Organizational Sciences, University of Belgrade, Serbia
}

BOJAN ILIĆ

Faculty of Organizational Sciences, University of Belgrade, Serbia

VESNA MILIĆEVIĆ

Faculty of Organizational Sciences, University of Belgrade, Serbia

\title{
MANAGERIAL DECISION MAKING AND COST REDUCTION FOR WIND DEPLOYMENT AS AN ALTERNATIVE ENERGY
}

\begin{abstract}
:
This paper analyses the modern aspect and framework of business decision making related to investments and cost reduction in wind energy companies. It describes different strategies of measuring the efficiency level of installed wind capacities. The research is presented with consideration to the methodology approach specific for wind energy. Special attention is given to the cost-effective business operations of contemporary systems of energy accumulation and the process of optimal decision making in the course of energy distribution. The focus is on the framework for sustainable business in compliance with complex external environment. The impact of unpredictable market and climate circumstances show the importance of the strategy mix and its role in creating value for the end-users of electrical energy. The dynamics of exploitation of the preferential conditions for wind energy companies is also important in the context of return on investment. The perspective of investing in wind energy projects is also given, along with the specificities of their implementation according to the principle of creating positive energy balance. The paper also points out the significance of government incentives and their variations. It also provides useful guidelines for successful business decision making for managers in wind energy.
\end{abstract}

\section{Keywords:}

business decisions, alternative energy sources, wind energy, investment, cost reduction, efficiency, market, tariff system.

JEL Classification: Q20, Q21, Q29 


\section{Introduction}

From the aspect of modern business, it is important to emphasize that the gradual substitution of conventional energy sources with alternative sources is consistent with the development of contemporary technological systems of electrical energy production. In late 2015, the share of wind energy in the global electrical energy production was assessed to $443 \mathrm{GW}$ (REN21, 2016). Development perspectives of investing in the diversified portfolio of wind energy results from a set of reasons that make this type of investment attractive, such as:

- eliminating the greenhouse effect;

- reducing the dependence on fossil fuels import;

- increasing economic competitiveness of the energy sector;

- growth of national and local industry;

- relatively short period of return on investment;

- providing sustainable aggregate offer in the energy sector.

It is assumed that replacing one standard power plant that produces electrical energy from coal with a power plant producing energy from wind would reduce the GHG (greenhouse gas emissions) by approximately 50\% (IPCC, 2014). High dependence on imported fossil fuels is a serious challenge even for developed countries. Thus the European Union, which had the greatest share in the global energy import, in 2011 reached the dependence on imported fossil fuels as high as $53.8 \%$ of the total energy needs (IIEA, 2013). The paradox in the excessive supply and exploitation of fossil fuels at inadequate prices is damaging to the ecological potential of the country, which further undermines the sustainability of the energy system.

Optimization of the import-export ratio of electrical energy is a prerequisite for creating positive investment climate. An example of efficient restructuring in the energy sector and direct effect of renewable energy sources on reduction of imported energy dependence is Ireland, which in 2012 cut the costs by 245 million euros, with reduced imported fuels dependence by $12.3 \%$ compared to 2008 (Scheer, Stanley and Clancy, 2014). Alternative sources of energy reserves have a direct impact on the improvement of energy balance and higher rate of export potential, since they can be considered national sources of energy that provide secure supply and stable production growth.

Efficiency of investing in wind energy depends on a large number of interrelated factors that indicate the current state of the energy sector and provide guidelines for its further development. Macroeconomic indicators, parameters of the current state and development of energy economics, energy dependence of a country, and energy balance are some of the measures of potential cost-effectiveness of investment. The analysis includes the incentives the state gives to privileged producers, as an essential factor of the formed structure of the energy sector. In assessing the efficiency of investment in wind energy, the elements and needs of the energy system need to be 
precisely and comprehensively defined and measured; also a strategic plan for investment has to be developed in accordance with the postulates of energy policy. Resource specialization specifies the position of economies with lack of capital, technology standstill and absence of innovative and entrepreneurial experience. Lack of financial resources in the national market can be overcome by clearly defined relation policies, incentives and production subsidies.

\section{Wind energy investment specificity}

Analysis of the energy market in condition of growing need for primary energy indicates numerous advantages of wind energy exploitation from the business point of view, with focus on cost-effectiveness and sustainability of investment. Compared to other forms of renewable energy sources, exploitation of the technical potential of the wind is distinctively more efficient, bearing in mind the stability of the energy supply and environmental protection. Modern approach to electrical energy production is based on social and economic cohesion that focuses on overcoming the information asymmetry, lack of market mechanisms and institutional limitations. Contribution to the productive process reflects on the social environment as well, which makes wind energy competitive in the terms of few large incentives. Considering the capital intensity of investments, state instruments can enhance the project course of business and introduce the necessary energy standards. Role of state mechanisms is significant in term of creating positive economic climate by public support to research and development in this field.

Research showed that a substantial share of anthropogenic GHG gases, which are present $39 \%$ more than in the pre-industrial period, comes from the exploitation of traditional energy sources (IPCC, 2014). Very slow change of climate intensity from 3 tones of $\mathrm{CO}_{2}$ per Mtoe (millions tones of oil equivalent) in 1970 to 2.7 tones of $\mathrm{CO}_{2}$ per Mtoe in 2010 show the necessity of incentives for renewable energy sources. It is estimated that the exploitation of oil will drop by 2050, while the use of nuclear energy will be inconsiderable in comparison with renewable energy sources. The table 1. shows the amount of $\mathrm{CO}_{2}$ emission per capita in $\mathrm{EU}$ in relation to the real life needs in contemporary environment:

Table 1 Categories of final energy consumption and $\mathrm{CO}_{2}$ gases

\begin{tabular}{|l|c|c|}
\hline Category & $\begin{array}{l}\text { Energy consumption } \\
\text { (GJ/per capita/per year) }\end{array}$ & $\begin{array}{l}\mathrm{CO}_{2} \text { emission by world } \\
\text { average (CO2/per } \\
\text { capita/per year) }\end{array}$ \\
\hline $\begin{array}{l}\text { Basic needs: } 100 \mathrm{kWh}+ \\
100 \mathrm{~kg} \text { oil/per capita/per } \\
\text { year }\end{array}$ & 5 & 0.41 \\
\hline $\begin{array}{l}\text { Productive usage: } 750 \\
\text { kWh }+150 \mathrm{~kg} \text { oil/per }\end{array}$ & 10 & 0.83 \\
\hline
\end{tabular}




\begin{tabular}{|l|c|c|}
\hline capita/per year & & \\
\hline $\begin{array}{l}\text { Modern society: } 2000 \\
\text { kWh }+375 \mathrm{~kg} \text { oil/ per }\end{array}$ & 25 & 2.1 \\
capita/per year & & \\
\hline EU average & 75 & 6.2 \\
\hline
\end{tabular}

Source: Chakravarty, Tavoni (2013), p. 70

New capacities of onshore wind farms were on their lowest point since 2008 (+34 GW), mostly due to inconsistent regulatory policy of preferential purchase prices (IEA, 2014). The level of annual revenue from produced electrical energy depends on the net amount of produced energy in $\mathrm{kWh}$. The production of electrical energy can be displayed through the ratio of capacity factor. The ratio shows the relation between the real volume of power plant production in a specific time-frame and maximum nameplate capacity of the plant.

Gross theoretical annual production capacity of a plant amounts to $8,760 \mathrm{MWh}$ (365 days $\times 24$ hours). Certainly, gross production capacity is impossible to reach in practice, so it serves only for the real capacity calculation. This capacity is calculated by subtracting the number of hours when the plant does not operate in full capacity from the gross capacity (Mendonça, Jacobs, Sovacool, 2010).

Bearing in mind that the natural properties of the environment where a power plant is constructed affect the efficiency of wind exploitation, the practical capacity of production varies by $20-30 \%$ depending on geographical features (BWEA, Garrad Hassan, 2009). The capacity utilization factor (CUF) greatly differs between the forms of energy. Thus, the CUF is calculated as a ratio between electrical energy actually produced and the potential that can be reached in theory. Calculated energy utilization crucially affects the scope of investment and further course of project financing. The revenues from the produced electrical energy vary depending on the calculated efficiency of installed capacities. The most applied methodology for measuring efficiency is the efficiency curve. Typical methodology approach differs depending on the type of renewable source that is being analyzed. Measuring and defining the efficiency curve for a potential construction site of a power plant is conducted for at least two years (Minić, 2011). By the method of correlation analysis, the collected data are compared with the data from meteorological stations and a time series is created to assess the level of energy source utilization. Evaluation of optimal utilization level is required for undisturbed capacity function. The analysis is significant for determining the upper tolerable limit of utilization, so as to avoid the turbine malfunction.

Wind energy is used as an adequate example for investigating the CUF distribution by the efficiency curve. Wind velocity typically follows the two-parameter Weibull distribution and Rayleigh distribution, which is its subset (it has one parameter). In general terms, wind turbines operate in maximum capacity only 700-1500 hours per year. According to research, some authors have found that factors specific for wind energy, such as supply and demand of wind turbines, labour costs and presence of 
large corporations in the market, have a greater impact on capital costs than the macroeconomic factors (BWEA, Garrad Hassan, 2009). The relation between macroeconomics and business of individual companies is very important.

With increasing demand for electrical energy, the economic efficiency of wind energy and significance of preferential purchase price system become more obvious. When the optimal business zone is established, the marginal costs of producing electrical energy from wind will drop as a result of the decrease in operational expenses, which will further enable the preferential tariff system to create profitable business in the long run. Thus the companies with transmission system of electrical energy will in the supply process give advantage to the wind energy companies; this is still termed Merit-order effect. Due to this effect the drop in average price changed considerably, from 1.7 EUR/MWh in 2001 to 7.83 EUR/MWh in 2006, on global level (Sensfuss, Ragwitz and Genoese, 2008).

\section{Cost-effective business in the field of wind energy}

A new approach to the strategy of modern companies in term of costs and business success is to develop a unique and sustainable path for creating value. Structural and creative drivers of costs are applied to facilitate strategic and operational decision making. Cost - effectiveness analysis is also significant, comparing the alternative flows of actions from the point of their costs and effectiveness in reaching some the company's specific goals (llić, Milićević, 2009). This is particularly important for business decision making in the field of alternative energy sources.

According to the U.S. DOE (United States Department of Energy) research in 2012, compared to the basis 2002, contemporary forms of wind mills towers affected the total capital costs alteration of $+8 /+12 /+20$ (most/expected/least \%), while in the same period they had an effect on the increase of the annual electrical energy production of $+11 /+11 /+11$ (most/expected/least \%) (Edenhofer et al., 2012).

Physical distance from the transmission mechanism increases the chance for costs occurrence, therefore it can be argued that the distance between the wind mill farm and the electric power system is in inverse proportion to the loss reduction value. It is important to consider the entire process of electrical energy transmission, and not only the local energy load locations. Marginal losses of connecting to the electric power system is also to be taken into account (Ackermann (Ed.), 2005). If the local accumulation power station causes reduction in energy transmission, the marginal losses will be reduced, so the new costs can be calculated by linearization of losses. According to research, it can be concluded that marginal losses are two times larger than average losses, which indicates that the rise or reduction of electric energy losses in the process of distribution from the wind generator to electric power system will depend on the wind mill location and location of the accumulation power station (Ackermann (Ed.), 2005). Their analysis is important also from the point of government 
incentives, which mostly cover only average energy losses of connecting with the electric power system and electrical energy transmission.

In conditions of rationalization in electrical energy production, government incentives are an essential element. The structure of incentives legislation depends on numerous factors based in national specificity and economic policy of the country. Subsidies in form of preferential purchase prices are an adequate example of ensuring cost-effective transitions towards sustainable energy development. Strategic framework of modern state legislation implies the need for various types of incentives, with the aim to establish a holistic approach. The influence of external environment indicates the significance of the strategy mix and its role in creating value for national market.

Feed-in tariff, initially adopted in the state of California in 1978, today represents the most used preferential measure in the wind energy. Since 1991, German feed-in tariff system influences the expansion of its application in Europe, thus defining new standards in support mechanisms and restructuring the energy sector. Companies supplying electrical energy in Germany originally paid the wind energy $90 \%$ of the average price charged to consumers. Since 2000, a fixed tariff was introduced of 9.1 $\mathrm{c} / \mathrm{kWh}$ in the first 5 years of operation, and $6.19 \mathrm{c} / \mathrm{kWh}$ in the next 15 years (Butler, Neuhoff, 2008). Digression of feed-in tariffs in Germany, along with bonuses for suppliers that modernize their equipment within 5 years, proved to be an efficient method in highly developed countries. However, in practice there is no unique tariff system adequate for all markets. The basic models of feed-in tariffs are (Mendonça, 2012):

- purchase obligation;

- stepped tariff;

- tariff digression;

- premium option;

- equal burden sharing;

- forecast obligation.

Within the European Union, there are considerable variations in the level of feed-in tariffs depending of the technological characteristics and requirements of wind mills farms. The average duration of government support in EU is 14 years. Variable elements of feed-in tariffs are considered especially challenging for regulation, and it might create complicated administrative procedures and lack of transparency. Also, a higher tariff for lower capacity plants can lead to a drop in system efficiency. In line with this, an increasing number of countries opt for the so-called premium feed-in tariffs. The premium tariff consists of two elements: the price of electrical energy in the market of traditional energy sources according to time-zone differences and a reduced tariff, which needs to be high enough to make the project profitable.

Movements of electrical energy market price have to be predicted with high certainty, so as to avoid the windfall profit. An upper and lower limit is introduced within the tariff, in order to sustain the financial stability of the project. Accordingly, Spain, which 
introduced the premium tariff in 1998, defined a payment span from $0.071 € / \mathrm{kWh}$ to $0.085 € / \mathrm{kWh}$ (Mendonça, Jacobs and Sovacool, 2010). An important prerequisite is to distinguish ownership in the field of energy production and transmission, and this is why the influence of location on the tariff rate is emphasized.

Average life-span of a windmill is 20 to 30 years, whereas the total return on investment usually takes about 15 years (Corsatea, Giaccaria and Arántegui, 2014). Based on this, it is crucial to adjust the incentives to the inflation movements. The inflation index can include a whole tariff or just a part of it, predominantly by adapting the tariff level in relation to the index of consumer prices. Tariffs are often indexed according to economic parameters that affect the total costs of electrical energy production, such as the labour force or used materials (eg. in France). The tariff index span in practice is finely tuned so that the return on investment is between $5 \%$ and $8 \%$ (Lovinfosse, Varone (Eds.), 2004).

In order to analyze the impact of different forms of government incentives in a broader context, we need to point out the division of wind energy projects by the financing phases, so as to define the optimum dynamics of using the preferential terms. A lack of consistency imposes the need for adequate categorization of economic indicators of risk assessment.

When a company gives pledge on cash flow of the project with a bank or other financial institution, which in the case of default claims ownership over certain mortgage assets, such financing is termed off-balance-sheet financing. It mainly means that the debtor company establishes a new business entity for special financing purposes, which cannot go bankrupt pursuant to the debt of the parent company (bankruptcy remote) (this phase comes later, as shown in figure 1).

\section{Figure 1 Phases in financing wind energy projects}

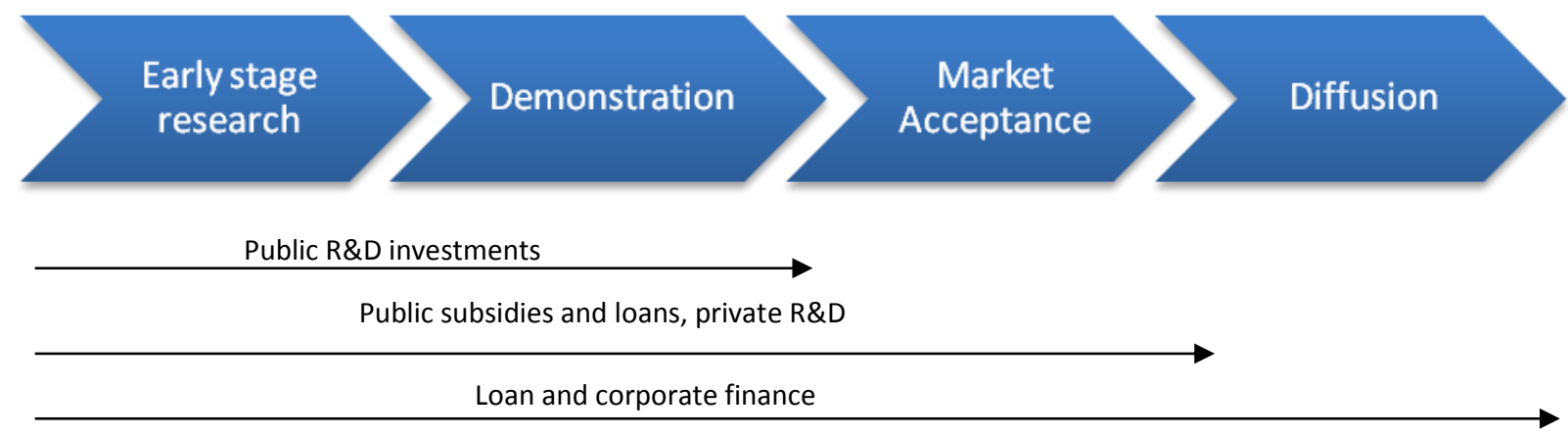

Source: Corsatea, Giaccaria and Arántegui, (2014), p. 142

The investor faces a potential loss of own capital, so its main concern is related to the reward they receive based on the placement of funds. The compensation they can receive is limited to assets and cash flow of the company. Moreover, if it happens that the company achieves greater success than expected, it will have a direct impact on the amount of funds that must be reimbursed. This is why for the investors it is more important to check the chances for inefficient business performance of the debtor. 
Introducing new mechanisms of support will be an additional motive for investors, and therefore the following could be applied:

- green certificates;

- green labels;

- subsidies;

- tax reliefs;

- access to energy of user's own choice;

- eco-tax.

Green certificates, subsidies and tax reliefs are the most common methods in the EU. The advantage of green certificates is that they cannot be classified as a form of subsidy or market intervention, they are proactive, market-oriented mechanisms that improve the negotiating position of investors.

By the unique responsibility principle, these certificates create a balance in the field of electrical energy trade, and often companies initiate their utilization. The system is based on quotas and green certificates, which are valid from 2 years to indefinite period, so as to protect the producers from political and economic instability.

Regulations in terms of quotas are imposed upon different groups: consumers (Denmark), electrical energy suppliers (Belgium, Great Britain), electrical energy producers (Italy) (Lovinfosse, Varone (Eds.), 2004). Some countries (Denmark, Belgium, Sweden) have legally prescribed minimum prices of green certificates for flexible adjustments in terms of external imbalances. Although the initial administrative costs are huge, the certificate system does not require direct interventions from the state budget, since the additional costs of wind exploitation are covered from the energy sector. Thus the financial burden is shifted from tax payers to electrical energy consumers (the so-called polluter pays). Therefore, it can be argued that green certificates have a positive effect on social equality. The greatest success has been achieved by fixed subsidies through tax loans in Denmark, where even $85 \%$ of electrical energy price comes from wind energy.

\section{Conclusion}

This paper analyses the effectiveness of government incentives in the wind energy from the aspect of business decision making. From the point of current conditions in the global market of energy resources, we can conclude that wind energy will have a significant role in future course of energy development. The scope and structure of preferential prices will indirectly shape the course of investments in terms of profitability and potential of substituting nonrenewable energy sources. The results show that investments in wind energy and their integration in the energy sector could substantially reduce harmful gas emissions. It is argued that this could eliminate the greenhouse effect, which gives additional advantage to this type of investment. Assumptions about the synergy effect in energy production and standardization of incentives arise from the 
current state of hyper-competition.

Strengthening the expertise through large investments in research and development provides certainty in predicting stable growth in utilization of these energy sources. Necessary restructuring of the energy sectors in transition countries will additionally boost the growth. In this context, the requirement of a set of government measures is emphasized, along with the increasing importance of business decision making on companies level.

\section{Reference}

ACKERMANN, T. (Ed.) (2005), Wind Power in Power Systems, New Jersey: John Wiley \& Sons Ltd.

BUTLER, L., NEUHOFF, K. (2008), Comparison of feed-in tariff, quota and auction mechanisms to support wind power development, Renewable Energy 33, pp. 1854-1867.

BWEA, GARRAD HASSAN (2009), UK Offshore Wind: Charting the Right Course, London: BWEA.

CHAKRAVARTY, S., TAVONI, M. (2013), Energy poverty alleviation and climate change mitigation: Is there a trade off?, Energy Economics 40.

CORSATEA, T. D., GIACCARIA, S., ARÁNTEGUI, R. L. (2014), The role of sources of finance on the development of wind technology, Renewable Energy 66.

EDENHOFER, O., MADRUGA, R. P., SOKONA, Y. (2012), Renewable Energy Sources and Climate Change Mitigation, Cambridge University Press.

IIEA (2013), EU Energy Import Dependence Infographic, Retrieved from: http://www.iiea.com/blogosphere/eu-energy-import-dependence, [Accessed: 28 February 2017].

ILIĆ, B., MILIĆEVIĆ, V. (2009), Menadžment troškova - Strategijski okvir, Beograd, Fakultet organizacionih nauka, Univerzitet u Beogradu.

IPCC (2014), Working Group III - Mitigation of Climate Change, Chapter 7 - Energy Systems.

LOVINFOSSE DE, I. \& VARONE F. (EDS.) (2004), Renewable Electricity Policies in Europe, UCL Presses.

MENDONÇA, M. (2012), Feed-in Tariffs: Accelerating the Deployment of Renewable Energy, Earthscan. MENDONÇA, M., JACOBS, D., SOVACOOL, B. (2010), Powering the green Economy, Earthscan.

MINIĆ, B. (2011), Procena efikasnosti ulaganja u sektor obnovljivih energija, Tematski zbornik radova Ekonomska politika i razvoj, Ekonomski fakultet, Beograd.

REN21 (2016), Renewables 2016 - Global Status Report, Paris: REN21 Secretariat.

SCHEER, J., STANLEY, S. AND CLANCY, M. (2014), Ireland's Sustainable Energy Supply Chain Opportunity, Dublin: SEAI

SENSFUSS, F., RAGWITZ, M., GENOESE, M. (2008), The Merit-order effect: A detailed analysis of the price effect of renewable electricity generation on spot market prices in Germany. 